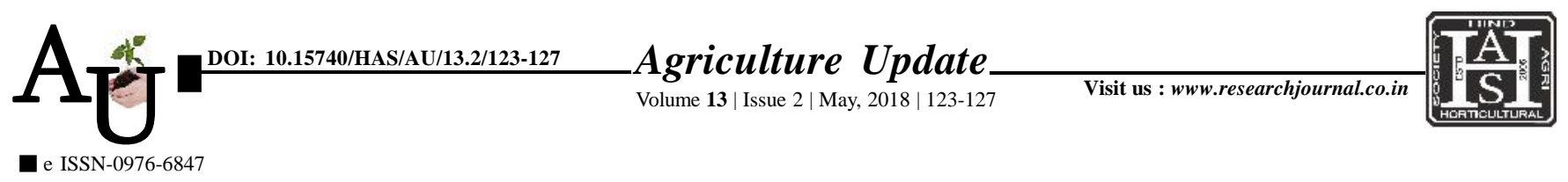

\title{
Research Article: Socio-economic profile and constraints faced by the members of milk producers co-operative societies in production and marketing of milk in Dharwad district of Karnataka- an analysis \\ Article Chronicle :
}

Received :

27.12.2017;

Revised :

15.03.2018;

Accepted :

01.04.2018

\section{KEY Words:}

Marketing, Problems, Production, Sample

Dairy Farmers, Socioeconomic

characteristics

Author for correspondence :

Priyadarshini C.

Gadal

Department of

Agricultural Economics,

College of Agriculture,

University of

Agricultural Sciences,

Dharwad (Karnataka)

India

Email:chintipriya@

gmail.com

See end of the article for

authors' affiliations

\author{
Priyadarshini C. Gadad and L.B. Kunnal
}

SUMMARY : The present study attempted to study the socio-economic profile of the sample dairy farmers and to document the problems faced by the members of milk producers co-operative societies in production and marketing of milk in Dharwad district. Multistage sampling procedure was followed for selection of 120 sample Dairy farmers. The data pertained to the agricultural year 2014-15. Tabular analysis and Garrett ranking technique were used to analyze the data. The socio-economic profile of the sample dairy farmers with respect to age, education, family size, type of family, occupation, experience in dairy farming and land holdings was studied. The results revealed that, majority of the farmers belonged to middle age group in the study area, it is observed that of the sample farmers 35 farmers belonged to small dairy farmers category, 55 belonged to medium category and 30 belonged to large category. Further, it is also observed that in the selected sample dairy farmers, majority of the farmers were educated, 24.17 per cent of the farmers had small land holding and semi medium land holding. It is observed that 69.17 per cent had medium experience in dairy farming and it can also be seen that 15.83 per cent of the farmers had dairy as a main occupation. High cost of cattle feeds and lack of good quality concentrates, non-availability of emergency veterinary services and artificial insemination facilities, high cost of cross-breed cattles, non-availability of improved breeds for milching, lack of grazing land and lack of technical know-how were the major problems faced by the dairy farmers in milk production. Low price, delayed payment, improper grading and malpractices in measurement of milk were the major problems faced by the dairy farmers in marketing of milk. Thus, the results of the study brings to focus that, the concerned agencies, development departments and others should focus more on dairy farmers by providing required facilities and other necessary help in effective running of dairy farming.

How to cite this article : Gadad, Priyadarshini C. and Kunnal, L.B. (2018). Socio-economic profile and constraints faced by the members of milk producers co-operative societies in production and marketing of milk in Dharwad district of Karnataka- an analysis. Agric. Update, 13(2): 123-127; DOI : 10.15740/HAS/AU/13.2/123-127. Copyright@2018: Hind Agri-Horticultural Society. 